\title{
EFFECTS OF DECOMPOSED POULTRY LITTER, NITROGEN AND PHOSPHORUS ON GROWTH AND MICRONUTRIENT CONTENT OF ARUM (Colocasia esculentus L.)
}

\author{
Uddin, M. K., J. Sultana, M. Alauddin, M. H. Rahman, M. Akhter, A. P. Rodrigues ${ }^{1}$, A. H. M. Z. Ali \\ and M. K. Rahman \\ Department of Soil, Water and Environment, University of Dhaka, Dhaka 1000, Bangladesh; \\ ${ }^{1}$ Department of Chemistry, Jahangirnagar University, Savar, Dhaka, Bangladesh
}

\begin{abstract}
A pot experiment was carried out to evaluate the integrated effects of poultry litter, nitrogen and phosphorus on the growth and micronutrient $(\mathrm{Fe}, \mathrm{Zn}$ and $\mathrm{Cu})$ contents of arum (Colocasia esculenta $\mathrm{L}$.) in the net house of the Department of Soil, Water and Environment, University of Dhaka. Height $(76 \mathrm{~cm})$, leaf number (5 no./plant), leaf area $\left(1045.66 \mathrm{~cm}^{2} /\right.$ plant $)$ and fresh $(130.7 \mathrm{~g} / \mathrm{plant})$ and dry $(14.35 \mathrm{~g} / \mathrm{plant})$ weights of leaf, stem, bulb and root were achieved highest in the combined application of decomposed poultry litter compost and nitrogen $\left(\mathrm{PL}_{2} \mathrm{~N}_{40} \mathrm{P}_{0}\right)$. The leaf area, and fresh and dry weights of leaf, stem, bulb and root varied significantly $(\mathrm{p} \leq 0.5)$. The concentration of iron, zinc and copper in different parts were measured the highest in the treatments $(0.70 \%),(0.58 \%),(0.22 \%)$ for leaf; $(0.83 \%),(0.96 \%),(0.99 \%)$ for stem; $(0.74 \%),(0.09 \%)$, $(0.05 \%)$ for bulb and $(0.98 \%),(0.64 \%),(0.27 \%)$ for root, respectively. Generally, the concentrations of $\mathrm{Fe}, \mathrm{Zn}$ and $\mathrm{Cu}$ were found to be the highest in $\mathrm{PL}_{4} \mathrm{~N}_{20} \mathrm{P}_{15}, \mathrm{PL}_{4} \mathrm{~N}_{0} \mathrm{P}_{15}$ and $\mathrm{PL}_{2} \mathrm{~N}_{0} \mathrm{P}_{0}$ treatments, respectively.
\end{abstract}

Key words: Arum, Biomass, Micronutrient, Poultry litter.

\section{INTRODUCTION}

The poultry industry is one of the largest and fastest growing agro-based industries in the world. This results the large-scale accumulation of wastes including manure and litters which may pose disposal and pollution problems unless environmentally and economically sustainable management technologies are evolved. Most of the litter produced by the poultry industry is currently applied to agricultural land as a source of nutrients and soil amendment. Its value as a nutrient source, soil amendment, animal feed (for cattle and fish) and fuel source and cost-effective innovative technologies for improving its value has been evaluated. Decomposed poultry litter provides a major source of nitrogen, phosphorus and trace elements for crop production and is effective in improving physical and biological fertility (Power and Dick 2000, Sharpley et al. 2007). Moreover, it improves organic matter content, water holding capacity, oxygen diffusion rate and the aggregate stability of the soils (Mahimairaja et al. 1995, Adeli et al. 2009).

Arum (Local name is panikachu) is an edible aroid making a significant contribution both as root crops and vegetables to the diets of the people of Bangladesh. Arum is widely distributed in humid tropics and subtropics. Of the tropical aroids, Colocasia esculenta L. is probably the most important as a food source. All parts of the plant including corm, cormels, rhizome, stalk, leaves and flowers are edible and are added to various food cultures. Arum is one of the few root and tuber crops that can grow well and has unique ability to withstand flooded and waterlogged or saturated soil conditions (Sivan 1980). A number of species of arum, viz. pani kachu, man kachu, gut kachu, bish kachu, ole kachu, and panchamukhi kachu are widely and commercially cultivated in Bangladesh. Pani kachu is extensively grown in kharif season. Among the tuber crops, corm and cormels of kachu are rich source of carbohydrate, vitamin A and $\mathrm{C}$, good source of iron and also contain sufficient quantity of protein (Verma and Singh 1996). It is the fourteenth most consumed vegetable in the world (Lebot and Aradhya 1991). In 2015, arum occupied near 25,048 hectares and the production of biomass was near 2,32,038 metric tons in Bangladesh (BBS 2015). The centre of origin of wild taro is generally believed to be 
between Myanmar and Bangladesh (Plucknett 1976). A little information is available in the literature on the cultivation of arum under Bangladesh edaphic conditions.

Thus, an experiment was conducted to evaluate the effect of decomposed poultry litter, nitrogen and phosphorus on growth, biomass production and micronutrient content $(\mathrm{Fe}, \mathrm{Zn}$ and $\mathrm{Cu}$ ) of arum.

\section{MATERIAL AND METHODS}

\section{Soil collection and characterization}

Soil sample (0-20) was collected from Ati, Keraniganj, Dhaka. The sample was air-dried, ground and sieved through $2 \mathrm{~mm}$ sieve. Soil had a $\mathrm{pH}$ of $6.86\left(1: 2.5 \mathrm{w} / \mathrm{v} \mathrm{H}_{2} \mathrm{O}\right.$ ), organic carbon $0.26 \%$ (Wet oxidation method, Jackson 1958), available nitrogen $24 \mathrm{mg} / \mathrm{kg}$ (Kjeldahl extraction, Marr and Cresser 1983), available phosphorous $6 \mathrm{mg} / \mathrm{kg}$ (Murphy and Riley 1962), sand 3.77\%, silt 68.23\% and clay $28.00 \%$, textural class - silt loam (Piper 1944), and water holding capacity was $33 \%$.

\section{Experiment}

A pot experiment was carried out in the Department of Soil, Water and Environment, University of Dhaka. Seven kg of soil were used per plastic pot (height $22 \mathrm{~cm}$ and diameter $27 \mathrm{~cm}$ ). Fifteen treatments with three replications each were as follows: $\mathrm{PL}_{0} \mathrm{~N}_{0} \mathrm{P}_{0}$ (Control), 2 ton PL/ha, 4 ton PL/ha, $\mathrm{PL}_{2} \mathrm{~N}_{20} \mathrm{P}_{0}$, $\mathrm{PL}_{2} \mathrm{~N}_{40} \mathrm{P}_{0}, \quad \mathrm{PL}_{2} \mathrm{~N}_{0} \mathrm{P}_{15}, \quad \mathrm{PL}_{2} \mathrm{~N}_{0} \mathrm{P}_{30}, \quad \mathrm{PL}_{4} \mathrm{~N}_{20} \mathrm{P}_{0}, \quad \mathrm{PL}_{4} \mathrm{~N}_{40} \mathrm{P}_{0}, \quad \mathrm{PL}_{4} \mathrm{~N}_{0} \mathrm{P}_{15}, \quad \mathrm{PL}_{4} \mathrm{~N}_{0} \mathrm{P}_{30}, \mathrm{PL}_{2} \mathrm{~N}_{20} \mathrm{P}_{15}, \mathrm{PL}_{2} \mathrm{~N}_{40} \mathrm{P}_{30}$, $\mathrm{PL}_{4} \mathrm{~N}_{20} \mathrm{P}_{15}$ and $\mathrm{PL}_{4} \mathrm{~N}_{40} \mathrm{P}_{30}$. Pots were arranged in a completely randomized design (CRD). Urea and triple super phosphate were used as sources of $\mathrm{N}$ and $\mathrm{P}$, decomposed poultry litter and seedlings of arum were collected from Charfession, Bhola district. Total N, P and K contents of decomposed poultry litter were $1.51 \%, 0.55 \%$ and $0.95 \%$, respectively. Three weeks old seedlings of arum were transplanted per pot. Seedlings were also collected from Charfession, Bhola district. The pots were watered $(1.5 \mathrm{~cm}$ height) daily in the morning. Inter cultural practices like weeding, pesticide application etc. were done as and when needed. The height of the plant was measured from the ground level to the tip of the leaflet, the numbers of leaves were counted and leaf area was measured at 10 day intervals. The plants were allowed to grow up to 70 days from transplanting. Arum seedlings and plants are shown in Fig. 1.

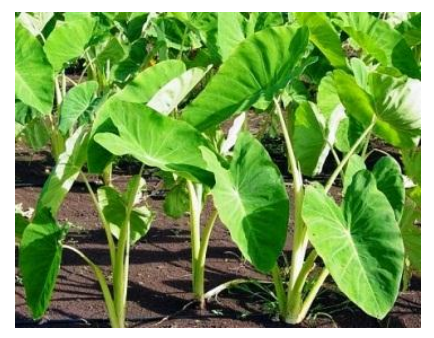

a.

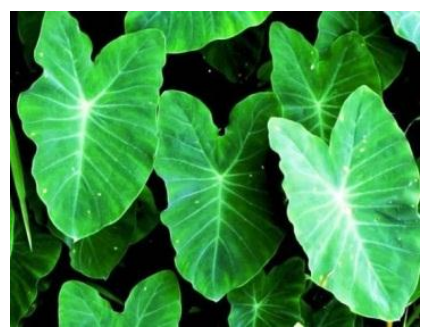

b.

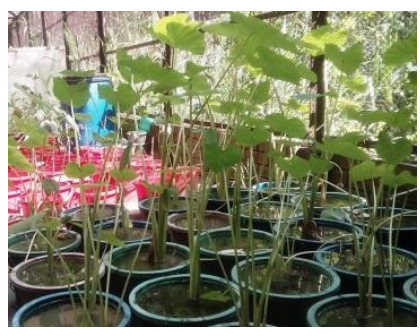

c.

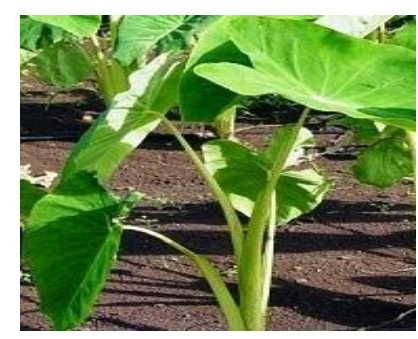

d.

Fig. 1. Arum seedlings and plants: a. arum culture in the field, b. arum leaves, c. seedlings in pot and d. arum plant.

\section{Harvesting and analysis}

The plants were harvested as leaf, stem, bulb and root, washed with tap water and deionized water, and wrapped with soft tissue paper. Immediately after harvest, fresh weight of leaf, stem, bulb and root were taken, air-dried in the room temperature and oven-dried at $65^{\circ} \mathrm{C}$ in the laboratory for two hours. Dry weight of the samples were measured, and ground with a mechanical grinder and stored in polyethylene bags for chemical analysis. The concentrations of iron, zinc and copper in leaf, stem, bulb and root were determined using an atomic absorption spectrophotometer (VARIAN AA240). LSD test of the results were performed using Minitab, version 17. 
Growth of the plants

\section{RESULTS AND DISCUSSION}

Plant growth was assessed in terms of plant height (Table 1), leaf number (Table 2) and leaf area (Table 3), and biomass production as leaf, stem, bulb and root (Table 4). Height values of 30, 40, 50 and 60 days varied significantly $(\mathrm{p} \leq 0.5)$ and of 10,20 and 70 days did not vary significantly (Table 1). However, the highest height $(76 \mathrm{~cm})$ was observed in combined application of decomposed poultry litter and nitrogen $\left(\mathrm{PL}_{2} \mathrm{~N}_{40} \mathrm{P}_{0}\right)$ after 70 days of growth. But spectacular differences were observed in treatments $\mathrm{PL}_{4} \mathrm{~N}_{20} \mathrm{P}_{0}(70.33 \mathrm{~cm})$ and $\mathrm{PL}_{2} \mathrm{~N}_{0} \mathrm{P}_{30}(69.33 \mathrm{~cm})$.

Table 1. Effects of decomposed poultry litter, nitrogen and phosphorous on the height (cm) of arum plants.

\begin{tabular}{lccccccc}
\hline Treatments (PL ton/ha & \multicolumn{6}{c}{ Height (cm) of arum plants (Days after transplanting) } \\
\cline { 2 - 7 } and N, P kg/ha) & $\mathbf{1 0}$ & $\mathbf{2 0}$ & $\mathbf{3 0}$ & $\mathbf{4 0}$ & $\mathbf{5 0}$ & $\mathbf{6 0}$ & $\mathbf{7 0}$ \\
\hline $\mathrm{PL}_{0} \mathrm{~N}_{0} \mathrm{P}_{0}$ & 24.00 & 32.66 & 33.66 & 37.00 & 43.66 & 49.00 & 52.00 \\
$\mathrm{PL}_{2} \mathrm{~N}_{0} \mathrm{P}_{0}$ & 30.33 & 40.66 & 42.66 & 44.66 & 48.66 & 51.00 & 53.33 \\
$\mathrm{PL}_{4} \mathrm{~N}_{0} \mathrm{P}_{0}$ & 24.33 & 32.33 & 37.66 & 45.66 & 52.33 & 53.66 & 55.66 \\
$\mathrm{PL}_{2} \mathrm{~N}_{20} \mathrm{P}_{0}$ & 24.66 & 40.33 & 45.66 & 50.66 & 54.00 & 55.66 & 57.33 \\
$\mathrm{PL}_{2} \mathrm{~N}_{40} \mathrm{P}_{0}$ & 30.33 & 46.66 & 56.66 & 64.00 & 71.66 & 74.33 & 76.00 \\
$\mathrm{PL}_{2} \mathrm{~N}_{0} \mathrm{P}_{15}$ & 27.33 & 35.66 & 37.33 & 42.00 & 46.00 & 48.00 & 49.00 \\
$\mathrm{PL}_{2} \mathrm{~N}_{0} \mathrm{P}_{30}$ & 31.00 & 42.66 & 48.00 & 57.33 & 64.00 & 67.66 & 69.33 \\
$\mathrm{PL}_{4} \mathrm{~N}_{20} \mathrm{P}_{0}$ & 35.66 & 47.33 & 52.33 & 60.00 & 63.00 & 69.00 & 70.33 \\
$\mathrm{PL}_{4} \mathrm{~N}_{40} \mathrm{P}_{0}$ & 28.33 & 32.33 & 41.00 & 44.66 & 47.33 & 50.66 & 55.00 \\
$\mathrm{PL}_{4} \mathrm{~N}_{0} \mathrm{P}_{15}$ & 26.00 & 35.66 & 39.66 & 50.33 & 57.33 & 59.00 & 60.66 \\
$\mathrm{PL}_{4} \mathrm{~N}_{0} \mathrm{P}_{30}$ & 32.33 & 49.33 & 54.66 & 61.33 & 66.00 & 67.66 & 69.33 \\
$\mathrm{PL}_{2} \mathrm{~N}_{20} \mathrm{P}_{15}$ & 26.33 & 33.66 & 41.00 & 47.00 & 51.00 & 57.00 & 61.33 \\
$\mathrm{PL}_{2} \mathrm{~N}_{40} \mathrm{P}_{30}$ & 28.33 & 45.00 & 49.66 & 55.66 & 60.00 & 63.33 & 65.33 \\
$\mathrm{PL}_{4} \mathrm{~N}_{20} \mathrm{P}_{15}$ & 25.33 & 28.33 & 39.66 & 45.33 & 48.00 & 50.66 & 52.66 \\
$\mathrm{PL}_{4} \mathrm{~N}_{40} \mathrm{P}_{30}$ & 28.00 & 39.33 & 40.66 & 44.33 & 49.33 & 53.00 & 56.00 \\
$\mathrm{LSD}_{\text {at }} \%$ & $\mathrm{NS}$ & $\mathrm{NS}$ & 10.14 & 11.31 & 12.07 & 11.44 & $\mathrm{NS}$ \\
\hline
\end{tabular}

Table 2. Effects of decomposed poultry litter, nitrogen and phosphorous on the leaf number/plant of arum plants.

\begin{tabular}{lccccccc}
\hline Treatments (PL ton/ha & \multicolumn{6}{c}{ Leaf (no./plant) of arum plants (Days after transplanting) } \\
\cline { 2 - 8 } and N, P kg/ha) & $\mathbf{1 0}$ & $\mathbf{2 0}$ & $\mathbf{3 0}$ & $\mathbf{4 0}$ & $\mathbf{5 0}$ & $\mathbf{6 0}$ & $\mathbf{7 0}$ \\
\hline $\mathrm{PL}_{0} \mathrm{~N}_{0} \mathrm{P}_{0}$ & 1.00 & 1.86 & 2.33 & 2.33 & 1.66 & 1.66 & 1.66 \\
$\mathrm{PL}_{2} \mathrm{~N}_{0} \mathrm{P}_{0}$ & 1.33 & 2.33 & 2.66 & 3.00 & 3.00 & 2.66 & 3.00 \\
$\mathrm{PL}_{4} \mathrm{~N}_{0} \mathrm{P}_{0}$ & 1.33 & 2.66 & 3.00 & 3.33 & 3.33 & 2.66 & 3.33 \\
$\mathrm{PL}_{2} \mathrm{~N}_{20} \mathrm{P}_{0}$ & 1.33 & 2.33 & 2.66 & 3.33 & 3.66 & 3.33 & 3.00 \\
$\mathrm{PL}_{2} \mathrm{~N}_{40} \mathrm{P}_{0}$ & 2.00 & 2.66 & 3.66 & 5.00 & 4.33 & 3.66 & 3.66 \\
$\mathrm{PL}_{2} \mathrm{~N}_{0} \mathrm{P}_{15}$ & 1.33 & 2.00 & 2.33 & 3.00 & 3.33 & 3.00 & 2.66 \\
$\mathrm{PL}_{2} \mathrm{~N}_{0} \mathrm{P}_{30}$ & 1.66 & 3.00 & 3.66 & 4.00 & 3.66 & 3.33 & 3.33 \\
$\mathrm{PL}_{4} \mathrm{~N}_{20} \mathrm{P}_{0}$ & 2.00 & 2.66 & 3.33 & 3.66 & 3.00 & 3.00 & 3.66 \\
$\mathrm{PL}_{4} \mathrm{~N}_{40} \mathrm{P}_{0}$ & 1.66 & 2.33 & 3.33 & 3.00 & 4.33 & 3.33 & 3.66 \\
$\mathrm{PL}_{4} \mathrm{~N}_{0} \mathrm{P}_{15}$ & 1.33 & 2.33 & 3.66 & 4.66 & 4.33 & 3.66 & 3.33 \\
$\mathrm{PL}_{4} \mathrm{~N}_{0} \mathrm{P}_{30}$ & 1.66 & 2.66 & 3.66 & 3.33 & 3.33 & 3.00 & 3.00 \\
$\mathrm{PL}_{2} \mathrm{~N}_{20} \mathrm{P}_{15}$ & 1.33 & 2.33 & 3.33 & 4.00 & 3.66 & 3.66 & 3.66 \\
$\mathrm{PL}_{2} \mathrm{~N}_{40} \mathrm{P}_{30}$ & 1.33 & 2.00 & 3.00 & 3.66 & 4.00 & 4.00 & 3.66 \\
$\mathrm{PL}_{4} \mathrm{~N}_{20} \mathrm{P}_{15}$ & 1.66 & 2.66 & 3.66 & 4.00 & 3.66 & 3.66 & 4.00 \\
$\mathrm{PL}_{4} \mathrm{~N}_{40} \mathrm{P}_{30}$ & 1.33 & 2.33 & 3.00 & 3.00 & 3.00 & 3.33 & 3.33 \\
$\mathrm{LSD}_{a} 5 \%$ & $\mathrm{NS}$ & $\mathrm{NS}$ & $\mathrm{NS}$ & 0.821 & 0.904 & 0.622 & 0.839 \\
\hline
\end{tabular}

Application of decomposed poultry manure based on crop $\mathrm{N}$ requirements is likely to provide more of other nutrients than is required by the crops (Edwards and Daniel 1992, Sims and Wolf 1994). The plant height was maximum in larger cormel size because of larger cormel had huge stored food material 
that support to increase vegetative growth of plants. Largest cormel size gave maximum vegetative growth and ultimately produced tallest plant (Thititaweesin et al. 2010).

The results of the leaf number per plant at 10 days interval are presented in Table 2. The leaf number increased up to 50 days and then decreased (Treatment PL2 ton/ha, N40 kg/ha and P0 kg/ha). It might be due to the combined application of nitrogen from poultry litter compost and urea fertilizer applied. However, leaf numbers were increased slightly the day 70 with the combined application of poultry litter compost, nitrogen and phosphorus (Treatments $\mathrm{PL}_{4} \mathrm{~N}_{20} \mathrm{P}_{0}, \mathrm{PL}_{4} \mathrm{~N}_{40} \mathrm{P}_{0}$ and $\mathrm{PL}_{4} \mathrm{~N}_{20} \mathrm{P}_{15}$ ). The leaf numbers of the plant at 40,50,60 and 70 day varied significantly $(\mathrm{p} \leq 0.5)$ initially up to 30 days, after that the leaf number did not vary significantly (Table 2 ). The minimum values of leaf number were recorded in control treatment $\left(\mathrm{PL}_{0} \mathrm{~N}_{0} \mathrm{P}_{0}\right)$.

Table 3. Effects of decomposed poultry litter, nitrogen and phosphorus on leaf area of arum plants.

\begin{tabular}{lccccccc}
\hline \multirow{2}{*}{$\begin{array}{l}\text { Treatments (PL ton/ha } \\
\text { and N, P kg/ha) }\end{array}$} & \multicolumn{6}{c}{ Leaf area $\left(\mathbf{c m}^{2} /\right.$ plant) of arum plants $($ Days after transplanting) } \\
\cline { 2 - 8 } & $\mathbf{1 0}$ & $\mathbf{2 0}$ & $\mathbf{3 0}$ & $\mathbf{4 0}$ & $\mathbf{5 0}$ & $\mathbf{6 0}$ & $\mathbf{7 0}$ \\
\hline $\mathrm{PL}_{0} \mathrm{~N}_{0} \mathrm{P}_{0}$ & 45.00 & 70.33 & 104.00 & 125.66 & 153.00 & 180.66 & 288.33 \\
$\mathrm{PL}_{2} \mathrm{~N}_{0} \mathrm{P}_{0}$ & 53.33 & 169.00 & 207.66 & 262.66 & 274.33 & 273.33 & 316.33 \\
$\mathrm{PL}_{4} \mathrm{~N}_{0} \mathrm{P}_{0}$ & 48.33 & 146.00 & 240.33 & 259.00 & 359.66 & 343.33 & 397.66 \\
$\mathrm{PL}_{2} \mathrm{~N}_{20} \mathrm{P}_{0}$ & 68.33 & 214.33 & 297.33 & 364.33 & 477.33 & 514.33 & 486.00 \\
$\mathrm{PL}_{2} \mathrm{~N}_{40} \mathrm{P}_{0}$ & 106.66 & 400.33 & 740.00 & 904.33 & 1007.66 & 1045.66 & 1012.66 \\
$\mathrm{PL}_{2} \mathrm{~N}_{0} \mathrm{P}_{15}$ & 51.66 & 109.00 & 144.33 & 196.66 & 265.00 & 270.33 & 231.66 \\
$\mathrm{PL}_{2} \mathrm{~N}_{0} \mathrm{P}_{30}$ & 58.33 & 312.66 & 513.66 & 610.66 & 762.00 & 755.00 & 732.00 \\
$\mathrm{PL}_{4} \mathrm{~N}_{20} \mathrm{P}_{0}$ & 81.66 & 230.33 & 325.00 & 381.00 & 509.00 & 528.33 & 479.33 \\
$\mathrm{PL}_{4} \mathrm{~N}_{40} \mathrm{P}_{0}$ & 50.00 & 81.33 & 139.00 & 184.66 & 261.33 & 321.33 & 376.33 \\
$\mathrm{PL}_{4} \mathrm{~N}_{0} \mathrm{P}_{15}$ & 48.33 & 155.00 & 348.66 & 469.00 & 554.00 & 640.00 & 651.33 \\
$\mathrm{PL}_{4} \mathrm{~N}_{0} \mathrm{P}_{30}$ & 86.66 & 363.66 & 536.00 & 648.00 & 664.33 & 651.33 & 576.00 \\
$\mathrm{PL}_{2} \mathrm{~N}_{20} \mathrm{P}_{15}$ & 51.66 & 130.00 & 188.00 & 263.66 & 390.33 & 390.66 & 394.66 \\
$\mathrm{PL}_{2} \mathrm{~N}_{40} \mathrm{P}_{30}$ & 46.66 & 160.00 & 235.66 & 352.33 & 431.66 & 504.00 & 553.00 \\
$\mathrm{PL}_{4} \mathrm{~N}_{20} \mathrm{P}_{15}$ & 53.33 & 125.33 & 180.00 & 241.66 & 311.33 & 323.66 & 332.66 \\
$\mathrm{PL}_{4} \mathrm{~N}_{40} \mathrm{P}_{30}$ & 48.33 & 128.33 & 172.33 & 224.00 & 272.33 & 302.33 & 301.33 \\
$\mathrm{LSD}_{4} \mathrm{at}_{5} \%$ & 20.14 & 140.40 & 252.00 & 295.38 & 323.15 & 307.80 & 310.29 \\
\hline
\end{tabular}

The results of the leaf area measurement are presented in Table 3. Leaf area was maximum with $\mathrm{PL}_{2} \mathrm{~N}_{40} \mathrm{P}_{0}$ treatment. The area gradually increased up to 70 days of growth. The values were 106.66, 400.33, 740.00, 904.33, 1007.66, 1045.66 and $1012.66 \mathrm{~cm}^{2}$ per plant on 10, 20, 30, 40, 50, 60 and 70 days, respectively (Table 3). The minimum values were obtained in the control treatment $\left(\mathrm{PL}_{0} \mathrm{~N}_{0} \mathrm{P}_{0}\right)$. Leaf area differs significantly in some same treatments over the control during the growth period $(\mathrm{p} \leq 0.5)$. The combined application of poultry litter and phosphorous showed second highest values $\left(\mathrm{PL}_{2} \mathrm{~N}_{0} \mathrm{P}_{30}\right)$, of $732 \mathrm{~cm}^{2} /$ plant of leaf area.

\section{Fresh and dry matter yield}

The yields of fresh and dry weights of leaf, stem, bulb and root are presented in Table 4 . The values for leaf, stem, bulb and root varied significantly $(\mathrm{p} \leq 0.05)$ for both fresh and dry weights in most of the treatments. The highest yields were achieved in $\mathrm{PL}_{2} \mathrm{~N}_{40} \mathrm{P}_{0}$ treatment. The fresh yields were 15.31, 77.74, 22.5 , and $15.15 \mathrm{~g} / \mathrm{plant}$ and dry weight values were $2.18,3.69,5.15$ and $3.33 \mathrm{~g} / \mathrm{plant}$ on day 70 after harvest, respectively (Table 4). The second highest values were recorded for fresh weights of leaf, stem, bulb and root were 10.85, 60.11, 8.27 and $7.46 \mathrm{~g} /$ plant and for dry weights were 1.54, 2.64, 1.71 and $1.70 \mathrm{~g} / \mathrm{plant}$ in the treatment $\mathrm{PL}_{2} \mathrm{~N}_{0} \mathrm{P}_{30}$, respectively. The minimum values for fresh weights were 2.03 , $14.40,1.55$ and $1.31 \mathrm{~g} /$ plant and for dry weights were $0.35,0.75,0.37$ and $0.31 \mathrm{~g} /$ plant for leaf, stem, bulb and root, respectively with the treatment $\mathrm{PL}_{0} \mathrm{~N}_{0} \mathrm{P}_{0}$ (Control). The maximum total yields of fresh and 
dry weights were 130.70 and $14.35 \mathrm{~g} /$ plant, respectively recorded with the treatment $\mathrm{PL}_{2} \mathrm{~N}_{40} \mathrm{P}_{0}$. It might be due to the decomposed poultry litter (PL) content nitrogen $1.5 \%$, phosphorous $0.55 \%$ and potassium $0.95 \%$. Besides, the present treatment $\mathrm{PL}_{2} \mathrm{~N}_{40} \mathrm{P}_{0}$ consists of the highest amount of nitrogen $(40 \mathrm{~kg} / \mathrm{ha})$. Probably the phosphorous demand of the plants was fulfilled by the decomposed poultry litter (P $0.55 \%)$. Nitrogen is most-imperative element for proper growth and development of plants which significantly increases the yield and its quality by playing vital role in biochemical and physiological functions of plant (Leghari et al. 2016). The result of the second total highest yield for fresh weight was $86.69 \mathrm{~g} / \mathrm{plant}$ and for dry weight were $7.59 \mathrm{~g} /$ plant with the treatment $\mathrm{PL}_{2} \mathrm{~N}_{0} \mathrm{P}_{30}$. The minimum values of the total fresh and dry weights were 19.29 and $1.78 \mathrm{~g} /$ plant, respectively.

Table 4. Effects of decomposed poultry litter, nitrogen and phosphorous on fresh and dry weights of arum plants.

\begin{tabular}{lccccc|ccccc}
\hline Treatments (PL ton/ha & \multicolumn{3}{c|}{ Fresh weight (g/plant) } & \multicolumn{4}{c}{ Dry weight (g/plant) } \\
\cline { 2 - 11 } and N, $\mathbf{P}$ g/ha) & Leaf & Stem & Bulb & Root & Total & Leaf & Stem & Bulb & Root & Total \\
\hline $\mathrm{PL}_{0} \mathrm{~N}_{0} \mathrm{P}_{0}$ & 2.03 & 14.40 & 1.55 & 1.31 & 19.29 & 0.35 & 0.75 & 0.37 & 0.31 & 1.78 \\
$\mathrm{PL}_{2} \mathrm{~N}_{0} \mathrm{P}_{0}$ & 2.76 & 17.79 & 8.34 & 2.06 & 30.95 & 0.48 & 0.88 & 2.03 & 0.46 & 3.85 \\
$\mathrm{PL}_{4} \mathrm{~N}_{0} \mathrm{P}_{0}$ & 3.37 & 19.88 & 2.34 & 2.32 & 27.91 & 0.52 & 0.93 & 0.51 & 0.49 & 2.45 \\
$\mathrm{PL}_{2} \mathrm{~N}_{20} \mathrm{P}_{0}$ & 3.46 & 24.88 & 9.07 & 5.32 & 42.73 & 0.48 & 1.06 & 2.02 & 1.17 & 4.73 \\
$\mathrm{PL}_{2} \mathrm{~N}_{40} \mathrm{P}_{0}$ & 15.31 & 77.74 & 22.50 & 15.0 & 130.70 & 2.18 & 3.69 & 5.15 & 3.33 & 14.35 \\
$\mathrm{PL}_{2} \mathrm{~N}_{0} \mathrm{P}_{15}$ & 2.42 & 19.35 & 2.04 & 1.51 & 25.32 & 0.39 & 1.02 & 0.43 & 0.35 & 2.19 \\
$\mathrm{PL}_{2} \mathrm{~N}_{0} \mathrm{P}_{30}$ & 10.85 & 60.11 & 8.27 & 7.46 & 86.69 & 1.54 & 2.64 & 1.71 & 1.70 & 7.59 \\
$\mathrm{PL}_{4} \mathrm{~N}_{20} \mathrm{P}_{0}$ & 5.08 & 32.18 & 2.37 & 2.66 & 42.29 & 0.76 & 1.59 & 0.52 & 0.61 & 3.48 \\
$\mathrm{PL}_{4} \mathrm{~N}_{40} \mathrm{P}_{0}$ & 3.69 & 30.03 & 1.86 & 1.65 & 37.23 & 0.64 & 1.45 & 0.43 & 0.37 & 2.89 \\
$\mathrm{PL}_{4} \mathrm{~N}_{0} \mathrm{P}_{15}$ & 6.37 & 51.39 & 4.34 & 4.80 & 66.90 & 1.18 & 2.55 & 0.96 & 1.19 & 5.88 \\
$\mathrm{PL}_{4} \mathrm{~N}_{0} \mathrm{P}_{30}$ & 7.06 & 38.60 & 3.73 & 3.14 & 52.53 & 1.06 & 1.99 & 0.82 & 0.69 & 4.56 \\
$\mathrm{PL}_{2} \mathrm{~N}_{20} \mathrm{P}_{15}$ & 5.24 & 27.61 & 3.22 & 2.41 & 38.48 & 0.75 & 1.42 & 0.62 & 0.53 & 3.32 \\
$\mathrm{PL}_{2} \mathrm{~N}_{40} \mathrm{P}_{30}$ & 5.60 & 47.28 & 3.55 & 1.92 & 58.35 & 1.08 & 2.48 & 0.83 & 0.46 & 4.85 \\
$\mathrm{PL}_{4} \mathrm{~N}_{20} \mathrm{P}_{15}$ & 3.44 & 23.42 & 2.59 & 2.11 & 31.56 & 0.66 & 1.10 & 0.56 & 0.45 & 2.78 \\
$\mathrm{PL}_{4} \mathrm{~N}_{40} \mathrm{P}_{30}$ & 2.61 & 19.75 & 2.05 & 2.52 & 26.43 & 0.44 & 0.98 & 0.44 & 0.63 & 2.49 \\
$\mathrm{LSD}_{\text {at }} 5 \%$ & 2.04 & 0.15 & 0.35 & 0.07 & - & 0.22 & 0.08 & 0.24 & 0.06 & - \\
\hline
\end{tabular}

\section{Micronutrient content}

The contents of iron, zinc and copper in leaf, stem are presenting in Table 5 and those of bulb and root are shown in Tables 6 . The micro-nutrient ( $\mathrm{Fe}, \mathrm{Zn}$ and $\mathrm{Cu}$ ) concentrations of both leaf and stem of arum plant were influenced by different rates of poultry manure, $\mathrm{N}$ and $\mathrm{P}$ application. It was revealed that the highest value of $\mathrm{Fe}(0.70 \%)$ in leaf was obtained with $\mathrm{PL}_{2} \mathrm{~N}_{0} \mathrm{P}_{15}$ treatment where poultry manure at a rate of 2 ton/ha in combination with $15 \mathrm{~kg} / \mathrm{ha}$ phosphorous were applied. The lowest value of $\mathrm{Fe}$ $(0.33 \%)$ was recorded with $\mathrm{PL}_{4} \mathrm{~N}_{0} \mathrm{P}_{30}$ treatment having poultry manure and phosphorous twice than $\mathrm{PL}_{2} \mathrm{~N}_{0} \mathrm{P}_{15}$ treatment (Table 5). For $\mathrm{Zn}$ content in leaf, the treatment $\mathrm{PL}_{2} \mathrm{~N}_{20} \mathrm{P}_{0}$ showed the highest value $(0.58 \%)$ and the lowest value $(0.10 \%)$ was recorded in $\mathrm{PL}_{4} \mathrm{~N}_{0} \mathrm{P}_{15}$ treatment. In leaf, when $\mathrm{Cu}$ concentration was considered, it was revealed that the highest and the lowest values of $\mathrm{Cu}(0.22 \%$ and $0.08 \%$ ) were recorded with $\mathrm{PL}_{2} \mathrm{~N}_{40} \mathrm{P}_{30}$ and $\mathrm{PL}_{4} \mathrm{~N}_{40} \mathrm{P}_{0}$ treatments (Table 5).

In case of stem, the highest concentration of $\mathrm{Fe}(0.83 \%)$ was recorded in $\mathrm{PL}_{4} \mathrm{~N}_{0} \mathrm{P}_{0}$ treatment where the highest rate of poultry manure (4 ton/ha) was added and the lowest value of $\mathrm{Fe}(0.23 \%)$ was obtained with control. The highest concentration of $\mathrm{Zn}(0.96 \%)$ in stem was found in $\mathrm{PL}_{4} \mathrm{~N}_{0} \mathrm{P}_{15}$ treatment where the highest dose of poultry manure (4 ton/ha) in combination with $15 \mathrm{~kg}$ of $\mathrm{P}$ were applied. The control treatment gave the lowest concentration of $\mathrm{Zn}(0.18 \%)$ in stem. When the percentage of $\mathrm{Cu}$ in stem is considered, it showed that the highest and the lowest values $(0.99 \%$ and $0.04 \%)$, respectively were obtained with $\mathrm{PL}_{2} \mathrm{~N}_{0} \mathrm{P}_{0}$ and $\mathrm{PL}_{4} \mathrm{~N}_{20} \mathrm{P}_{0}$ treatments, respectively. The concentration of $\mathrm{Zn}$ and $\mathrm{Cu}$ were higher in stem compared to leaf sample. However, the percentage of Fe was higher in leaf than that of 
stem in arum plant. In Table 5, the results of iron, zinc and copper in leaf and stem didn't vary statistically.

Table 5. Concentration (\%) of $\mathrm{Fe}, \mathrm{Zn}$ and $\mathrm{Cu}$ in the leaf and stem of arum plants.

\begin{tabular}{lccc|ccc}
\hline \multirow{2}{*}{$\begin{array}{l}\text { Treatments (PL ton/ha } \\
\text { and N, P kg/ha) }\end{array}$} & \multicolumn{3}{c|}{ Leaf } & \multicolumn{3}{c}{ Stem } \\
\cline { 2 - 7 } & Fe & $\mathbf{Z n}$ & $\mathbf{C u}$ & $\mathbf{F e}$ & $\mathbf{Z n}$ & $\mathbf{C u}$ \\
\hline $\mathrm{PL}_{0} \mathrm{~N}_{0} \mathrm{P}_{0}$ & 0.41 & 0.30 & 0.12 & 0.23 & 0.18 & 0.16 \\
$\mathrm{PL}_{2} \mathrm{~N}_{0} \mathrm{P}_{0}$ & 0.43 & 0.13 & 0.10 & 0.25 & 0.18 & 0.99 \\
$\mathrm{PL}_{4} \mathrm{~N}_{0} \mathrm{P}_{0}$ & 0.46 & 0.34 & 0.10 & 0.83 & 0.70 & 0.76 \\
$\mathrm{PL}_{2} \mathrm{~N}_{20} \mathrm{P}_{0}$ & 0.61 & 0.58 & 0.18 & 0.53 & 0.58 & 0.17 \\
$\mathrm{PL}_{2} \mathrm{~N}_{40} \mathrm{P}_{0}$ & 0.55 & 0.44 & 0.14 & 0.44 & 0.29 & 0.23 \\
$\mathrm{PL}_{2} \mathrm{~N}_{0} \mathrm{P}_{15}$ & 0.70 & 0.33 & 0.13 & 0.47 & 0.36 & 0.08 \\
$\mathrm{PL}_{2} \mathrm{~N}_{0} \mathrm{P}_{30}$ & 0.59 & 0.20 & 0.10 & 0.42 & 0.27 & 0.08 \\
$\mathrm{PL}_{4} \mathrm{~N}_{20} \mathrm{P}_{0}$ & 0.49 & 0.13 & 0.18 & 0.44 & 0.19 & 0.04 \\
$\mathrm{PL}_{4} \mathrm{~N}_{40} \mathrm{P}_{0}$ & 0.52 & 0.42 & 0.08 & 0.63 & 0.58 & 0.12 \\
$\mathrm{PL}_{4} \mathrm{~N}_{0} \mathrm{P}_{15}$ & 0.58 & 0.10 & 0.12 & 0.62 & 0.96 & 0.40 \\
$\mathrm{PL}_{4} \mathrm{~N}_{0} \mathrm{P}_{30}$ & 0.33 & 0.15 & 0.11 & 0.52 & 0.55 & 0.15 \\
$\mathrm{PL}_{2} \mathrm{~N}_{20} \mathrm{P}_{15}$ & 0.38 & 0.14 & 0.10 & 0.70 & 0.19 & 0.09 \\
$\mathrm{PL}_{2} \mathrm{~N}_{40} \mathrm{P}_{30}$ & 0.48 & 0.31 & 0.22 & 0.81 & 0.74 & 0.19 \\
$\mathrm{PL}_{4} \mathrm{~N}_{20} \mathrm{P}_{15}$ & 0.64 & 0.27 & 0.09 & 0.81 & 0.84 & 0.22 \\
$\mathrm{PL}_{4} \mathrm{~N}_{40} \mathrm{P}_{30}$ & 0.38 & 0.22 & 0.16 & 0.73 & 0.60 & 0.18 \\
$\mathrm{LSD}_{4} 5 \%$ & $\mathrm{NS}$ & $\mathrm{NS}$ & $\mathrm{NS}$ & $\mathrm{NS}$ & $\mathrm{NS}$ & $\mathrm{NS}$ \\
\hline
\end{tabular}

Results obtained due to effect of poultry litter, $\mathrm{N}$ and $\mathrm{P}$ fertilizers on both bulb and root revealed that the percentage of $\mathrm{Fe}, \mathrm{Zn}$ and $\mathrm{Cu}$, were very low in bulb compared to root (Table 6). The highest percentage of $\mathrm{Fe}(0.74 \%)$ in bulb was obtained with $\mathrm{PL}_{2} \mathrm{~N}_{40} \mathrm{P}_{30}$ treatment. In case of $\mathrm{Zn}$ and $\mathrm{Cu}$ in bulb, the maximum and minimum values of $\mathrm{Zn}$ ranged from 0.02 to $0.09 \%$ and for $\mathrm{Cu}$, it varied from 0.01 to $0.05 \%$, respectively. For root samples, the percentages of $\mathrm{Fe}, \mathrm{Zn}$ and $\mathrm{Cu}$ were higher than those of bulb samples.

Table 6. Concentration (\%) of $\mathrm{Fe}, \mathrm{Zn}$ and $\mathrm{Cu}$ in the bulb and root of arum plants.

\begin{tabular}{lccc|ccc}
\hline \multirow{2}{*}{$\begin{array}{l}\text { Treatments (PL ton/ha } \\
\text { and N, P kg/ha) }\end{array}$} & \multicolumn{3}{c|}{ Bulb } & \multicolumn{3}{c}{ Root } \\
\cline { 2 - 7 } & $\mathbf{F e}$ & $\mathbf{Z n}$ & $\mathbf{C u}$ & $\mathbf{F e}$ & $\mathbf{Z n}$ & $\mathbf{C u}$ \\
\hline $\mathrm{PL}_{0} \mathrm{~N}_{0} \mathrm{P}_{0}$ & 0.13 & 0.04 & 0.02 & 0.42 & 0.3 & 0.11 \\
$\mathrm{PL}_{2} \mathrm{~N}_{0} \mathrm{P}_{0}$ & 0.18 & 0.06 & 0.03 & 0.73 & 0.39 & 0.11 \\
$\mathrm{PL}_{4} \mathrm{~N}_{0} \mathrm{P}_{0}$ & 0.05 & 0.07 & 0.03 & 0.92 & 0.39 & 0.18 \\
$\mathrm{PL}_{2} \mathrm{~N}_{20} \mathrm{P}_{0}$ & 0.21 & 0.03 & 0.01 & 0.74 & 0.31 & 0.25 \\
$\mathrm{PL}_{2} \mathrm{~N}_{40} \mathrm{P}_{0}$ & 0.14 & 0.05 & 0.02 & 0.70 & 0.31 & 0.27 \\
$\mathrm{PL}_{2} \mathrm{~N}_{0} \mathrm{P}_{15}$ & 0.49 & 0.06 & 0.02 & 0.55 & 0.32 & 0.18 \\
$\mathrm{PL}_{2} \mathrm{~N}_{0} \mathrm{P}_{30}$ & 0.4 & 0.03 & 0.02 & 0.61 & 0.64 & 0.23 \\
$\mathrm{PL}_{4} \mathrm{~N}_{20} \mathrm{P}_{0}$ & 0.54 & 0.02 & 0.01 & 0.71 & 0.35 & 0.18 \\
$\mathrm{PL}_{4} \mathrm{~N}_{40} \mathrm{P}_{0}$ & 0.09 & 0.07 & 0.01 & 0.60 & 0.47 & 0.15 \\
$\mathrm{PL}_{4} \mathrm{~N}_{0} \mathrm{P}_{15}$ & 0.21 & 0.04 & 0.02 & 0.69 & 0.34 & 0.13 \\
$\mathrm{PL}_{4} \mathrm{~N}_{0} \mathrm{P}_{30}$ & 0.37 & 0.04 & 0.03 & 0.72 & 0.37 & 0.15 \\
$\mathrm{PL}_{2} \mathrm{~N}_{20} \mathrm{P}_{15}$ & 0.02 & 0.09 & 0.02 & 0.75 & 0.25 & 0.1 \\
$\mathrm{PL}_{2} \mathrm{~N}_{40} \mathrm{P}_{30}$ & 0.74 & 0.05 & 0.04 & 0.60 & 0.11 & 0.07 \\
$\mathrm{PL}_{4} \mathrm{~N}_{20} \mathrm{P}_{15}$ & 0.42 & 0.07 & 0.05 & 0.98 & 0.42 & 0.2 \\
$\mathrm{PL}_{4} \mathrm{~N}_{40} \mathrm{P}_{30}$ & 0.15 & 0.03 & 0.02 & 0.99 & 0.07 & 0.08 \\
$\mathrm{LSD}_{2}{ }_{5} \%$ & $\mathrm{NS}$ & $\mathrm{NS}$ & $\mathrm{NS}$ & $\mathrm{NS}$ & $\mathrm{NS}$ & 3.38 \\
\hline
\end{tabular}

The highest values of Fe concentration (0.98\%) in root was recorded with $\mathrm{PL}_{4} \mathrm{~N}_{20} \mathrm{P}_{15}$ treatment and $\mathrm{PL}_{0} \mathrm{~N}_{0} \mathrm{P}_{0}$ (control) treatment resulted the lowest value $(0.42 \%)$. The highest value of $\mathrm{Zn}(0.64 \%)$ was 
obtained with $\mathrm{PL}_{2} \mathrm{~N}_{0} \mathrm{P}_{30}$ treatment and $\mathrm{PL}_{4} \mathrm{~N}_{40} \mathrm{P}_{30}$ treatment gave the lowest value of $\mathrm{Zn}(0.07 \%)$. In case of $\mathrm{Cu}$ in root the highest and the lowest values were $0.27 \%$ and $0.07 \%$ recorded in $\mathrm{PL}_{2} \mathrm{~N}_{40} \mathrm{P}_{0}$ and $\mathrm{PL}_{2} \mathrm{~N}_{40} \mathrm{P}_{30}$ treatments, respectively (Table 6). The results of iron, zinc and copper in bulb and root didn't vary statistically where the values of copper in root vary significantly $(p \leq 0.05)$.

The experiment revealed that the most effective treatment was $\mathrm{PL}_{2} \mathrm{~N}_{40} \mathrm{P}_{0}$ to increase the leaf, stem, bulb and root production. The increased concentrations of $\mathrm{Fe}, \mathrm{Zn}$ and $\mathrm{Cu}$ were observed in the treatments of $\mathrm{PL}_{4} \mathrm{~N}_{20} \mathrm{P}_{15}, \mathrm{PL}_{4} \mathrm{~N}_{0} \mathrm{P}_{15}$ and $\mathrm{PL}_{2} \mathrm{~N}_{0} \mathrm{P}_{0}$, respectively.

\section{REFERENCES}

Adeli, A., H. Tewolde, K. R. Sistani and D. E. Rowe. 2009. Broiler litter fertilization and cropping system impacts on soil properties. Agron. J. 110: 1304-1310.

BBS. 2015. Yearbook of Agricultural Statistics. Statistics Division, Bangladesh Bureau of Statistics, Ministry of Planning, Government of the People's Republic of Bangladesh, Dhaka. 261pp.

Edwards, D. R. and T. C. Daniel. 1992. Environmental impacts of on-farm poultry waste disposal-A review. Bioresour. Technol. 41: 9-33.

Jackson, M. L. 1958. Soil Chemical Analysis. Prentice-Hall Inc., Englewood Cliffs, NJ. 498 pp.

Lebot, V. and K. M. Aradhya. 1991. Isozyme variation in taro (Colocasia esculenta L. Schott) from Asia and Oceania. Euphytica 56: 55-66.

Leghari, S. J., N. A. Wahocho, G. M. Laghari, A. H. Laghari, G. M. Bhabhan, K. H. Talpur, T. A. Bhutto, S. A. Wahocho and A. A. Lashari. 2016. Role of nitrogen for plant growth and development: a review. Advances Environ. Biol. 10(9): 209-218.

Mahimairaja, S., N. S. Bolan and M. J. Hedley. 1995. Dissolution of phosphate rocks during the composting of poultry manure. Fertilizer Res. 40: 93-104.

Marr, I. L. and M. S. Cresser. 1983. The Lithosphere In: Environmental Chemical Analysis. Blackie and Son, UK, pp. 155-182.

Murphy, J. and J. P. Riley. 1962. A modified single solution method for the determination of phosphate in natural waters. Anal. Chim. Acta. 27:31-36.

Plucknett, D. L. 1976. Edible aroids: Alocasia, Colocasia, Cyrtosperma, Xanthosoma. In: Simmonds, N. W. (ed.). Evolution of crop plants. Longman, London, pp. 10-12.

Power, J. F. and W. A. Dick. 2000. Land Application of Agricultural, Industrial, and Municipal Byproducts. SSSA Inc., Madison, WI. 625 pp.

Piper, C. S. 1944. Soil and Plant Analysis. The University of Adelaide, Australia, pp. 47-79.

Sharpley, A. N., S. Herron and T. Daniel. 2007. Overcoming the challenges of phosphorus based management challenges in poultry farming. J. Soil Water Conserv. 58: 30-38.

Sims J. T. and D. C. Wolf. 1994. Poultry waste management: agricultural and environmental issues. Advances Agron. 52: 1-83.

Sivan, S. 1980. Review of taro research and production in Fijii. In: Chandra, S. (ed.). Edible Aroids. Oxford Univ. Press, Oxford, UK, pp. 52-63.

Thititaweesin, S., S. Detpiratmongkol and S. Yoosukyingsataporn. 2010. Effects of corm size on growth and yield of taro. Proc. 48th Kasetsart Univ. Annl. Conf., Kasetsart. pp. 43-48. 
Verma, R. B. and P. K. Singh. 1996. Effect of nitrogen and potassium levels on growth, yield and nutrient uptake of Colocasia. J. Root Crops. 22(2): 139-143.

DOI: $\underline{\text { http://dx.doi.org/10.3329/jbcbm.v4i1.37872 }}$ 